\title{
The Effectiveness of Treatment Based on Acceptance and Commitment to Improving Psychological Well-Being of Transsexual Individuals Esfahan
}

\author{
Farzane Pourkazem Mohammad Fereidani ${ }^{1,}$,, Ronak Eshghi Nogourani ${ }^{2}$ \\ Department of Psychology,Esfahan Branch, Islamic Azad University,Esfahan iran (Corresponding Author) \\ Farzanepourkazem@gmail.com \\ Assistant Professor, Department of Psychology,Esfahan Branch, Islamic Azad University,Esfahan iran \\ Ronak_Eshghi@yahoo.com
}

\begin{abstract}
Introduction: The objective of this research was to determine the effectiveness of Acceptance and Commitment Therapy (ACT) on the psychological well-being increase of transsexuals.

Method: The pre-test-post-test control group design was used, in which due to participants' loss and their special conditions, only 20 transsexuals that visited the TS clinic in the 1395 summer were chosen considering the study criterion and were randomly placed in two groups: a) the experiment group (10 people), b) the control group (10 people). In this study the Ryff's psychological well-being scales-the short form- was used as an assessment tool. The Multivariate Analysis of Covariance (MANCOVA) was used for data analysis.

Results: The MANCOVA results indicated that ACT was effective on the psychological well-being increase of transsexuals $(\mathrm{P}<0.05)$. The following items probably lead to an increase of the participants' psychological well-being: creating approval and inclination, concentrating on/commitment to values.

Conclusion: According to the results of this research, ACT could be used in order to increase
\end{abstract} the psychological well-being of transsexuals.

Key words: psychological well-being, acceptance and commitment therapy, transsexual 


\title{
اثربخشى درمان مبتنى بر بذير ش و تعهد برافزايش بهزيستى روانشناختى افراد ترا جنسى
}

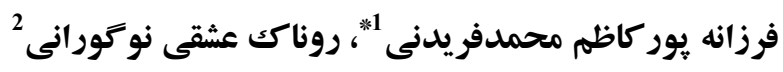

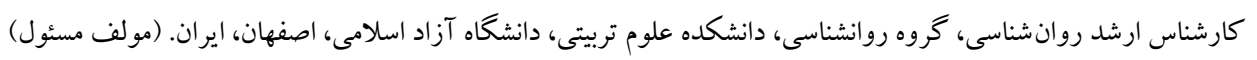 \\ farzanepourkazem@gmail.com \\ استاديار، كروه روانشناسى، دانشخاه آزاد اسلامى، اصفهان، ايران \\ Ronak_Eshghi@yahoo.com
}

جكکيده

مقدمه: اين بثروهش بهمنظور اثربخشى درمان مبتنى بر بذيرش و تعهد (ACT) برافزايش بهزيستى روانشناختى افراد تراجنسى

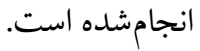

روش: روش بررسى نيمه آزمايشى از نوع ييش آزمون- يس آزمون با گروه كنترل بود كه به دليل ريزش مر اجعله كندكان و خاص

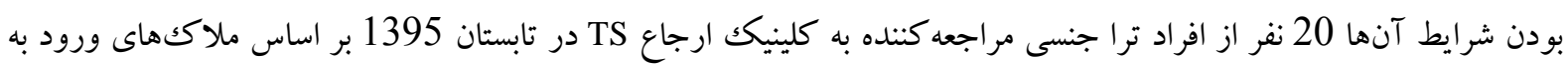

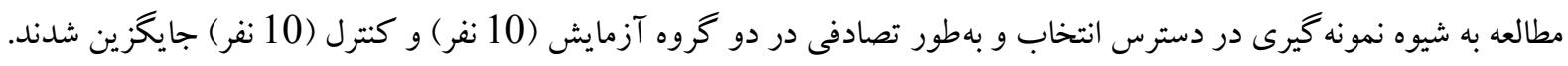

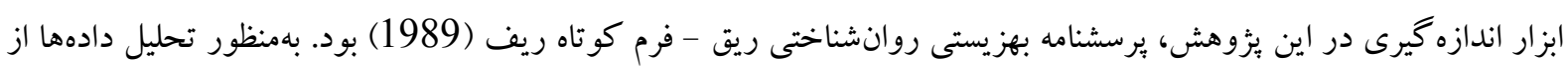

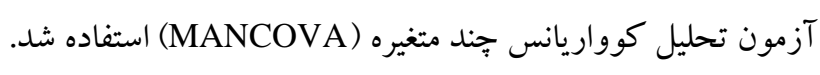

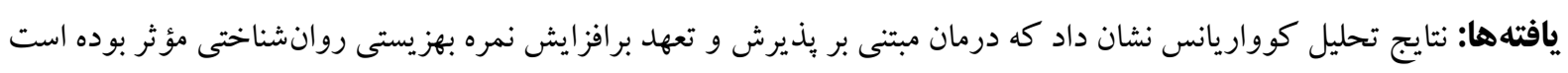

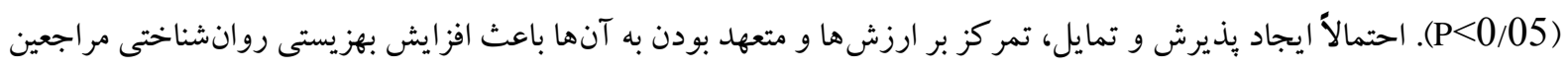
كروه يذيرش و تعهد شده است.

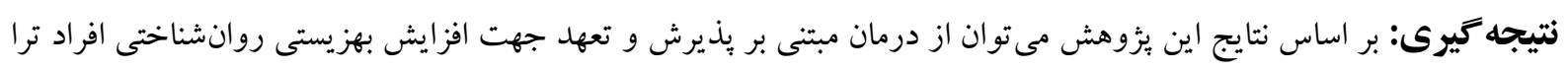
جنسى استفاده نمود. كليد وازهها: بهزيستى روانشناختى، درمان مبتنى بر يذيرش و تعهد، ترا جنسى 
جنسى و هويت فرد در مورد كرايش جنسى كامل نيست؛ توجه به اين نكته هم لازم است كه سنجش كرايى جنسى با يكك يا دو برسش مستقيم ممكن است بهور دقيق امكانيذير نباشد. گرايش جنسى و ور كاه ترجيح جنسى (كه البته دقت كمترى دارد) ممكن است

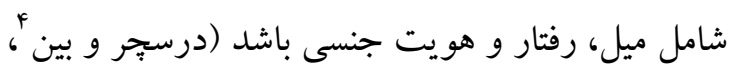
.2009

ابتلا به نارضايتى جنسيتى افراد را در معرض انواع

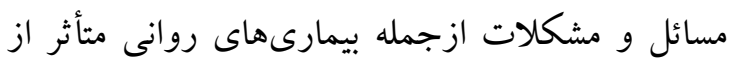
وضعيت آنها قرار مىدهند يكى از اين جمله مشكلات كاهش بهزيستى روانشناختى و سلامت روان است (ريف و كيزه، 1995). تحقيقات نشان داده است كه ونس عوامل متعددى بر روى بهزيستى روانشناختى تأثير گذار هستند كه شامل رضايت درونى، درآمد،

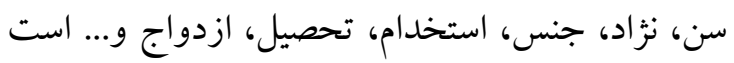
و هر كدام از اين عوامل متعدد كه در فرد با نقصان و كمبود مو اجه باشد به طبع آن بهزيستى روانشناختى و سلامت روان فرد را تحت تأثير قرار مىدهد (رحيميان بو گر '، 1386). بهزيستى روانشناختى به معناى قابليت يافتن تمام استعدادهاى فرد است؛ و داراى مؤلفههاى 1- خودمختارى (احساس شايستكى و توانايى در

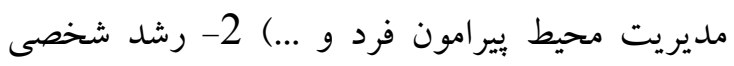
(داشتن رشد مداوم و ...) 3- روابط مثبت با ديخران

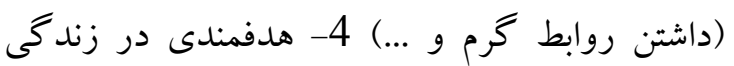
(داشتن هدف در زندكى) 5- بذيرش خود (داشتن نغرش مثبت نسبت به خود و ...) 6- تسلط بر محيط (توانايى انتخاب و ايجاد محيطى مناسب و...) است (ريف و كيز، 1995). (روان)

4- Drescher, Byne

5- Ryff, Keyes

6- Rahimian مقلdمه

سر آغاز هر رفتار جنسى، جنسيت است. جنسيت هر

انسان به عنوان زن يا مرد كه از همان دوران جنينى و زمانى كه در رحم رشد مى كند مشخص مىشود و شايد اولين منبع براى نوع رفتار جنسى در آينده باشد؛ جر اكه نوع جنسيت، رفتارهاى جنسى خاص و منحصر بهفردى را به ارمغان خوراهد آورد. فارغ از اينكه هويت جنسى با مفاهيم فيزيكى (مانند تركيب كروموزومها، آلت جنسى مردانه يا زنانه و ظاهر فيزيكى مردانه يا زنانه) ارتباط دارد، اين مقوله در بر گيرنده ويز گیىهاى روانشناختى و سازههاى اجتماعى و فرهنگى نيز هست (قاعدى'، 1392)؛ اما اين فرايند طبيعى كه در اكثريت موارد با موفقيت طى مى گردد، در بارهاى موارد مسير متفاوتى را مى كذراند، بهطورى كه كودك در مورد تعلق خود به يكى از دو جنس دجار ترديد شده يا كاملاً خود را متعلق به جنس مخالف جنسيت بيولوزيكك خود مىداند كه در اين وضعيت وى دجٍار اختلال هويت جنسى مىشود. جِنين وضعيتى معمولاً با رشد كودكك ادامه مىيابد و در مواردى نيز به قوت ادامه يافته و به حداكثر شدت خود يعنى تقاضاى فرد براى تغيير مشخصات آناتوميك خود به صورت جنسيتى كه فرد خود را متعلق به آن مىداند، برسد به اين دسته از افراد ترا جنسى كفته مىشود (سادوكى، سادو كك و روئيز ، 2015). در حد اطلاع نويسند گان تاكنون آمارى رسمى از افراد داراى اختلال هويت جنسى در جمعيت طبيعى ايران وجود ندارد و بر اساس گز ارش آمار سلامت ملى ايالت متحده 2 درصد زنان و 6 درصد مردان 44-25 سابقه تماس جنسى با فرد همجنس خود داشتهاند (جاندرا و موشر ׳م، 2011). بنابراين انطباق ميان رفتار

\footnotetext{
1-ghaedi

2-Sadouk,Rouiez

3- Chandra, Mosher
} 


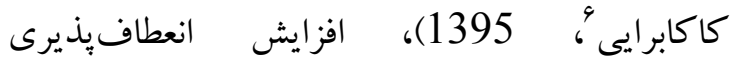

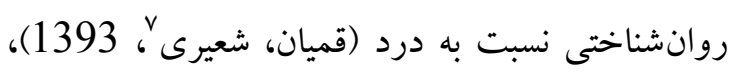
كاهش كلى علائم اضطراب فراكير (علوى زاده، شاكريان، 1395) افزايش تابآورى و سطح اميد به

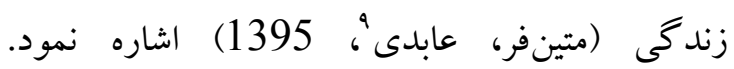
يُوهش هاى زيادى در ايران در مورد افراد تراجنسى

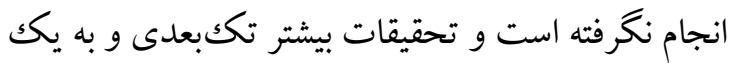
شيوه درمان اشارهشده است. نتايج اين يثروهش مى تواند به هموار شدن مسير مطالعات بيشتر در اين زمينه كمكك كند. ازآنجاكه درمان مبتنى بر يذيرش و تعهد يكك

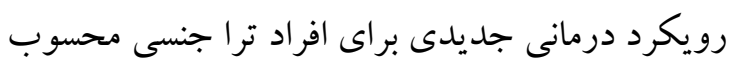
مىشود و تاكنون در زمينهى افزايش بهزيستى رونى روانشناختى افراد ترا جنسى استفاده نشده است و اين

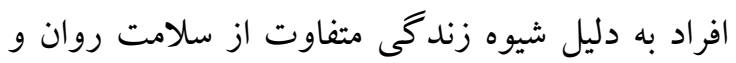
بهزيستى روانى كمترى برخوردار هستند لذا لزوم توجه به اين بسيار نمايان مى شود و اين بزوهش در استان اصفهان انجام نشده است در نتيجه ضرورت انجام يُزوهش نيز نشان داده مىشود. بر اين اساس در اين يُروهش سعى بر آن است كه به اين سؤال ياسخ داده

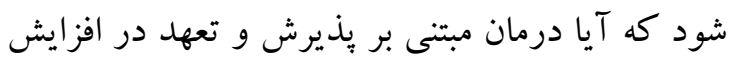
بهزيستى روانشناختى افراد تراجنسى تأثير معنادارى بـى بـري دارد؟

\section{روش بررسى}

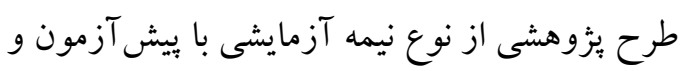
يس آزمون با گرووه كنترل بود. جامعه آمارى شامل كليه افراد تراجنسى در شهر اصفهان در تابستان سال 1395 به مراكز ارجاع TS مراجعه كرده بودند. روش نمونه-

$$
\text { كيرى از نوع در دسترس بود. }
$$

6- Sabour, Kakabaraie

7- Ghomian, Shaieri

8- Alavie, Shakerian

9- Matin far, Abedi
درمان مبتنى بر بذيرش و تعهد يكى از درمانهاى

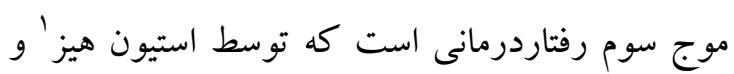
همكارانش از ابتداى دهه 1980 معرفى و با نام اختصارى ACT شناخته شده است و ريشه در فلسفه

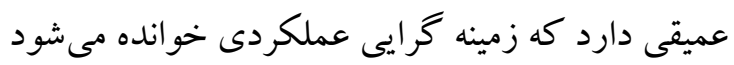

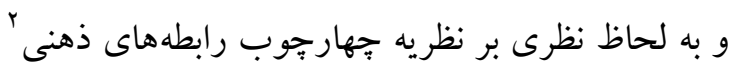
است كه جِگونخى ايجاد رنج توسط ذهن انسان و روشهاى بىفايده مقابله با آن و نيز رويكردهاى زمينهاى جايگزين براى اين حوزهها را تبيين مى كند. در اصل يكك رفتاردرمانى است و موضوع آن ACT عمل است اما نه هر عملى بلكه عملى كه اول ارزش

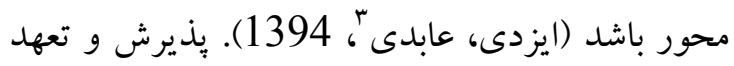

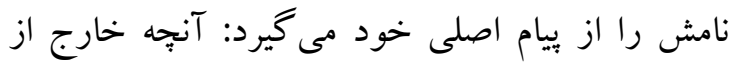
كنترل شخصىات است را بيذير و به عملى كه

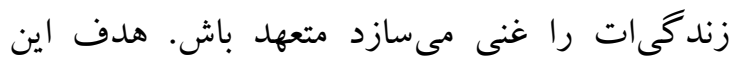

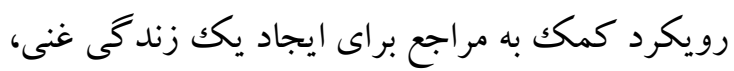
كامل و معنادار است در عين بذيرش رنجى كه زند

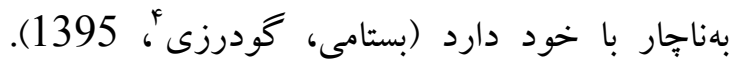

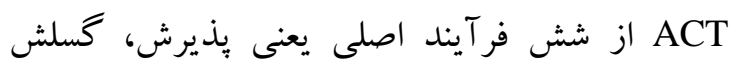

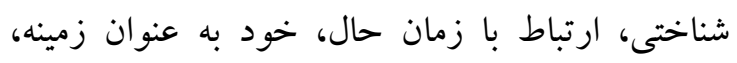
ارزشها و اقدام متعهدانه براى انعطافيذيرى روانشناختى استفاده مى كند (هيز، لوما و و بوندهاء

.2006

يثزوهشهاى متعددى دال بر وجود رابطه بين يذيرش و تعهل و بهزيستى روانشناختى و اثربخش بودن درمان مبتنى بر پيذيرش و تعهد بر كاهش

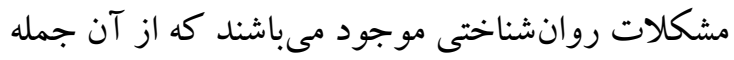
مىتوان به اثربخش بودن درمان مبتنى بر بذيرش و و

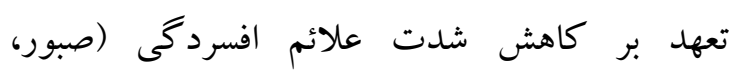

1- Steven Hayes

2- Relationship Framework Teory (RFT)

3- Ezadi, Abedi

4- Bastami,Goudarzi

5- Louma, Bond 
6)، رشد فردى (7-15-17)، روابط مثبت با ديخران

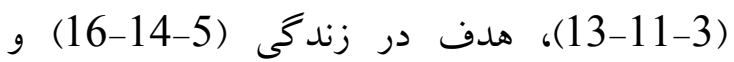

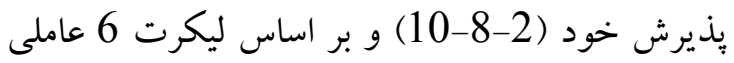

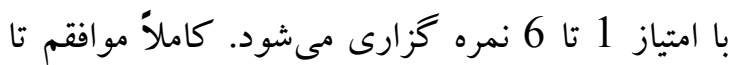
حدى موافقم، موافقم، مخالفم تا حدى مخالفم و كاملاًا

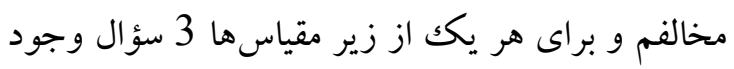

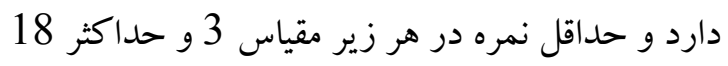
است اين برسشنامه كه براى بزر كسالان تهيه شده است همسانى درونى كل اين آزمون در يزوهش حاضر در برد مطالعه آزمايشى بر روى 35 نفر از دانشجويان با آلفاى كرونباخ 0/76 و بر روى 343 نفر از دانشجويان

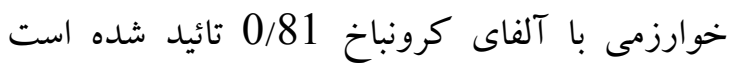
(ريف و همكاران، 1989).

در يزوهش حاضر همسانى درونى مقياس از طريق

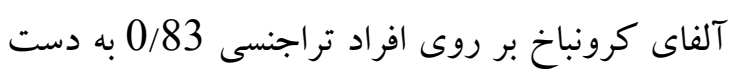

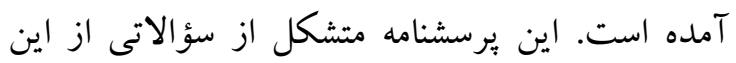
قبيل است: من بيشتر جنبههاى شخصيتم را دوست دارم.

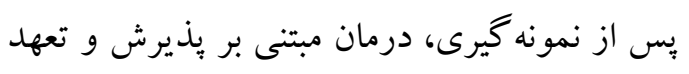

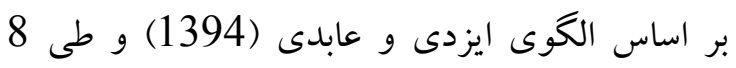

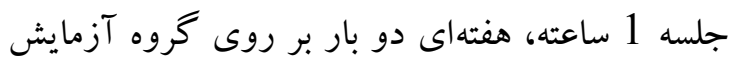

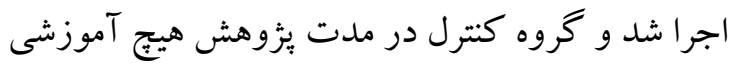
دريافت نكردند. دوره اجراى آموزش سه هفته از تاريخ

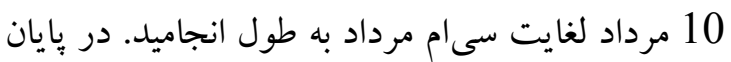
آموزش، پِ آزمون روى هر دو گروه اجرا شد. شرح

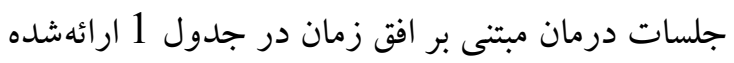

به اين صورت كه از ميان افراد تراجنسى كه به 2 كلينيك ارجاع TS مراجعه كردهاند و با مصاحبه بالينى زير نظر روانشناسان و بر اساس ضوابط تشخيصى بنجمين ويرايش راهنماى تشخيصى و و آمارى بيمارىهاى روانى (DSM-5) تشخيص اختلال نارضايتى جنسيتى داده شده است و به دليل ريزش اين افراد در مرحله انتخاب 20 نفر به صورت تصادفى نادي انتخاب و بهصورت تصادفى در دو گروه كواه (10 نراب نفر) و آزمايش (10 نفر) قرار گرفنتد. معيارهاى ورود به مطالعه شامل 1 (دارا بودن برونده مراجعه كمتر از يكك سال 2) دارا بودن حداقل تحصيلات سيكل 3 (نداشتن يك دوره سايكوز، مانيا، هييو مانياو يا اختلال شخصيت كه بهوسيله تست Mوني قابل تشخيص است 4 (نداشتن اعتياد و هركونه سوءمصرف مواد كه به وسيله آزمايش تشخيص اعتياد قابل تشخيص است 5) عدم دريافت هركونه درمان روانشناختى ديخر و معيارهاى خروج از مطالعه شامل 1) داشتن غيبت بيش از دو جلسه 2) نداشتن انكيزه براى درمان روانشناختى و انجام تكليف. ير بشنامه بهزيستى روانشناختى ريف: بهمنظور سنجش سلامت روانشناختى فردى ازئ مقياس بهزيستى روانشناختى ريف استفاده مى شود. ريف اين آزمون را در فرمهاى بلند 84 سؤالى، متوسط روان

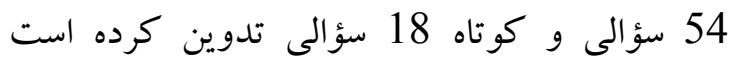
(ريف، سينگر و لاو، 1998). نسخه كوتاه اين بر سشنامه 6 مؤلفه اصلى الكوى بهزيستى روانشناختى

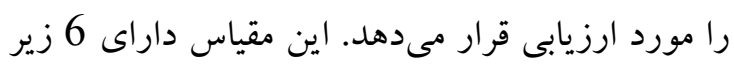

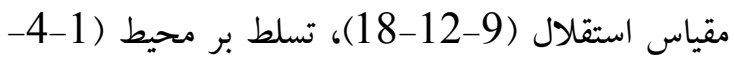


جدول 1: شرح جلسات درمان مبتنى يذيرش و تعهد

\begin{tabular}{|c|c|}
\hline 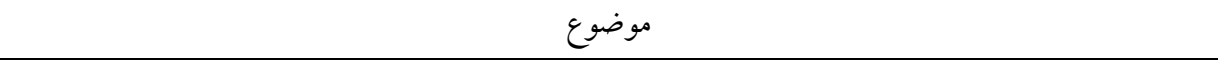 & جلسات \\
\hline آشنايى و معارفه و بيان اهداف كار كاه، اجراى بيش آزمون & اول \\
\hline شناسايى درمان يذيرش و تعهد، اهداف و محورهاى درمان، اطلاعاتى در مورد اختلال، تكليف خانكى & دوم \\
\hline ايجاد ناميدى خلاقانه، ارزيابى تمايل براى تغيير، جمعبندى، تكليف خانكى & سوم \\
\hline بررسى جلسه گذشته، تشخيص راهبردهاى ناكار آمد، مفهوم يذيرش، جمعبندى، تكليف خانكى & جهارم \\
\hline بررسى جلسه كذشته، تكليف و تعهد رفتارى، كاربرد تكنيك كسلش شناختى & ينجم \\
\hline بررسى جلسات كذشته، مشاهده خود بهعنوان زمينه، تضعيف خود مفهومى، جمعبندى، تكليف خانكى & ششم \\
\hline بررسى جلسات گذشته، شناسايى ارزشها، تصريح و تمركز بر آنها، موانع درونى و بيرونى، جمعبندى جلسه & هفتم \\
\hline بررسى جلسات گذشته، درك ماهيت تمايل و تعهد، مفهوم عود و آماد گى مقابله با آن، اجراى بس آزمون & هشتم \\
\hline
\end{tabular}

ي بيش فرض هاى آزمونهاى بِارامتريك،، از آزمون تحليل كوواريانس جند متغيره (MANCOVA) استفاده شد.

\section{يافتهها}

نتايج آمارى بهدست آمده از بزوهش حاضر در دو بخش آمار توصيفى و استنباطى ارائه مى گردد. جدول

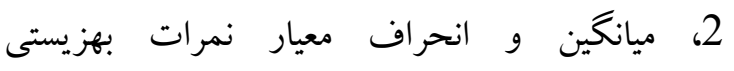
روانشناختى را نشان مىدهد.
براى تحليل دادههاى حاصل از برسشنامهاى يثوهش از نرمافزار SPSS و از دو سطح آمار توصيفى

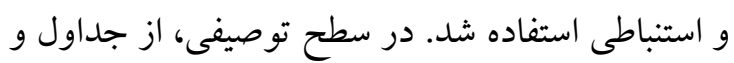

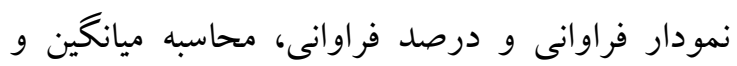
انحراف معيار و در سطح استنباطى نيز در راستاى

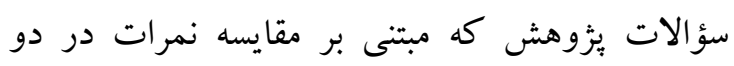

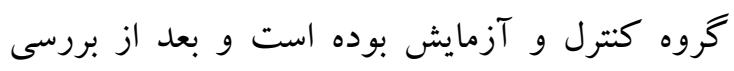

جدول 2: ميانكين و انحر اف معيار بهزيستى روانشناختى

\begin{tabular}{|c|c|c|c|}
\hline كنترل & آزمايش & \multirow{2}{*}{ 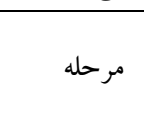 } & \multirow{2}{*}{ 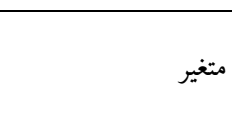 } \\
\hline ميانكين (انحراف استاندارد) & ميانگين (انحر اف استاندارد) & & \\
\hline $67 / 400$ & $56 / 600$ & بيش آزمون & \multirow{2}{*}{ بهزيستى روانشناختى } \\
\hline $68 / 550$ & $69 / 500$ & 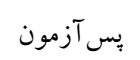 & \\
\hline
\end{tabular}

(p>0/05)

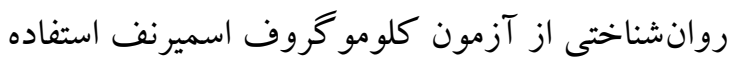

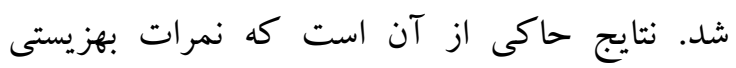
روانشناختى نرمال است (p>0/05). بر اين اساس، مى توان از آزمون تحليل كواريانس جند متند متغيره استفاده

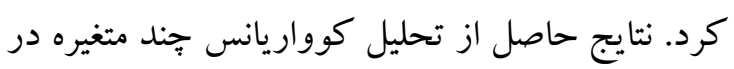

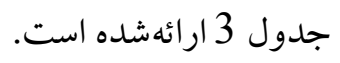

نتايج جدول 2 نشان مىدهد ميانگين نمرات بهزيستى روانشناختى در گروه آزمايش در مرحله يس آزمون نسبت به مرحله بيش آزمون افزايش داشته

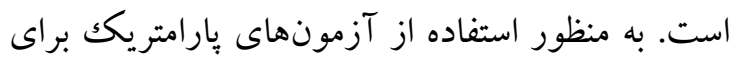
بررسى تساوى واريانس نمرات بهزيستى روانشناختى

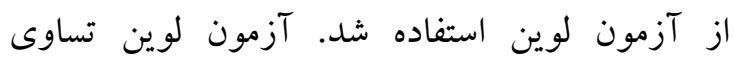
واريانس هاى نمرات بهزيستى روانشناختى را نشان داد 
جدول 3: تحليل كوواريانس درمان مبتنى بر هذيرش و تعهد بر بهزيستى روانشناختى افراد تراجنسى دحانى

\begin{tabular}{|c|c|c|c|c|c|c|c|}
\hline 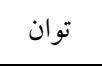 & اتا & سطح معنادارى & $\mathrm{F}$ & ميانگين مجذورات & درجه آزادى & مجموع مجذورات & منبع \\
\hline 0/997 & $0 / 584$ & $0 / 000$ & $25 / 241$ & $1338 / 962$ & 1 & $1338 / 962$ & يِيش آزمون \\
\hline $0 / 783$ & $0 / 319$ & $0 / 01$ & $8 / 416$ & $449 / 779$ & 1 & $449 / 779$ & يس آزمون \\
\hline
\end{tabular}

توانسته است نمرات بهزيستى روانشناختى در مرحله يس آزمون را افزايش دهد. ميزان تأثير يا تفاوت برابر 0/31 است، يعنى 31 درصد تفاوتهاى فردى در نمرات بهزيستى روانشناختى افراد داراى اختلال نارضايتى جنسى مربوط به تأثير درمان مبتنى بر يذيرش و تعهد است. اين نتيجه از يزوهش حاضر با نتايج بثزوهش قميان و شعيرى (1393)، مقتدايى و خوش اخلاق (1394)، صديقى (1394) كه نشان دادند درمان مبتنى بر يذيرش و تعهد منجر به بهبود بهزيستى روانشناختى در بيماران مىشود همخوان است. اين نتيجه از يثزوهش حاضر همجينين با نتايج يثوهشهاى ورايى (1392)، علوى و جلالى (1393)، خوشدل و جفرودى (1392) و هايس (2004) همسو است، هايس نشان داد كه روش درمان مبتنى بر يذيرش و تعهد و نقش آن در ساز گارى و بهزيستى روانشناختى و بهبود روابط اجتماعى و همجينين ساز گارى بهتر كودكان مبتلابه مشكلات رفتارى است. سعادتمند و بساكى نزاد' (1395) نيز نشان دادند كه اثربخشى زوجدرمانى مبتنى بر بذيرش و تعهد بر صميميت، بخشش و بهزيستى روانشناختى زوجها تأثير مطلوبى داشته است. در تبين اين يافته از تحقيق مىتوان كفت رويكرد درمانى مبتنى بر يذيرش و تعهد بهجاى آنكه روى برطرف سازى و حذف عوامل آسيبزا تمركز نمايد، به مراجعين كمكك مى كند تا شناختهاى كنترلشده
همانطور كه نتايج جدول 3 نشان مىدهد بين كروهها در نمرات بهزيستى روانشناختى در مرحله يس آزمون در سطح P>0/05 تفاوت معنىدار وجود دارد. تفاوت بين نمرات بهزيستى روانشناختى در كروه آزمايش و كنترل در مرحله يُ آزمون معنىدار است. يعنى درمان مبتنى بر بذيرش و تعهد توانسته است نمرات بهزيستى روانشناختى در مرحله يس آزمون را افزايش دهد. علاوه بر اين مشخص مىشود كه ميزان اين تأثير 31 درصد است. دوره بيگيرى به دليل حساس بودن كروه آزمايش و عدم همكارى آنها به دلايل متعدد من جمله مشكلات خانو ادگى صورت نكرفت.

جهت بررسى تأثير بذيرش و تعهد در بهبود بهزيستى روانشناختى از تحليل كواريانس جند متغيره استفاده شد. نتايج نشان داد كه بين علائم بهزيستى روانشناختى افراد تراجنسى كروههاى آزمايش و كنترل تفاوت معنادارى وجود دارد. طبق اطلاعات موجود در جدول (2) ميانگين و انحراف معيار نمرات بس آزمون بهزيستى روانشناختى در گرووه آزمايش نسبت به بيش آزمون افزايش داشته است. درصورتى كه اين افزايش نمره يس آزمون نسبت به بيش آزمون در كروه كنترل مشاهده نشد. همجينين نتايج جدول (3) نشان مىدهد بين گروهها در نمرات بهزيستى روانشناختى در مرحله يس آزمون تفاوت معنىدار وجود دارد. يعنى درمان مبتنى بر يذيرش و تعهد 
تراجنسى مؤثر بوده است؟ بهعبارتديخر با جه سازوكارى مىتوان اين اثربخشى را تبيين نمود؟ برى بره بهزيستى روانشناختى فرايندى است كه در آن تلاش

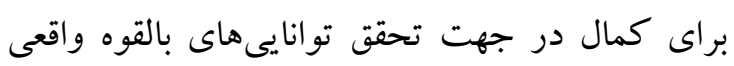

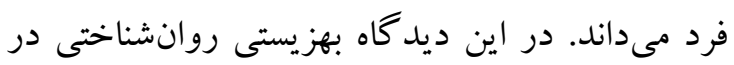
تلاش براى ارتقا استعداد و توانايىهاى فرد تجلى مىشود (ريف 1995). ابعاد بهزيستى روانشناختى

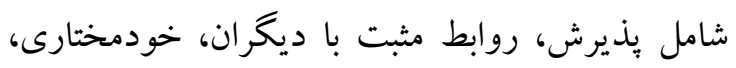
زندكى هدفمند، رشد شخصى، تسلط محيطى است بت رونت

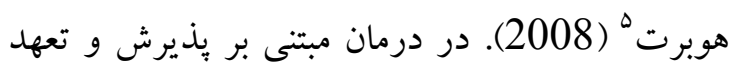
تلاش براى كنترل بهبود سلامت روان، مستلزم فكر كردن به مسائلى است كه بهزيستى و سلامت روان بران را تحريك مى كند و در نتيجه آن ناميدى و ناراحتى احضار مىشود و اين امر در مرحله گسلش از درمان مبتنى بر يذيرش و تعهل به وجود مى آيد.

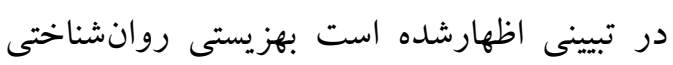

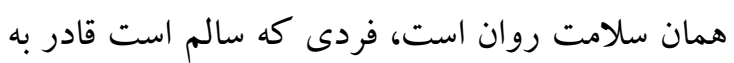

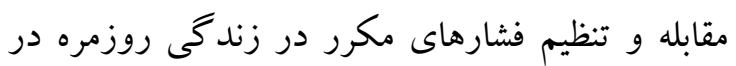

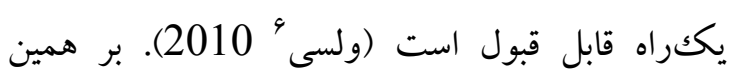
اساس مى توان كفت با افزايش بهزيستى روانشناختى بر روى افراد گروه و روش دستيابى به سلامت روان ران

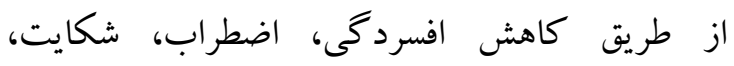
خود گويى منفى و ضريب ناراحتى را فراهم مى آورد. در طى درمان مبتنى بر بذيرش و تعهد تمايل جايخزين

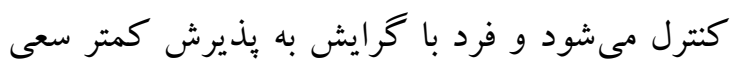

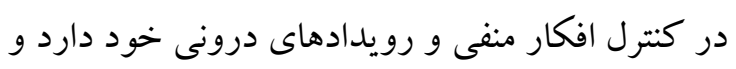

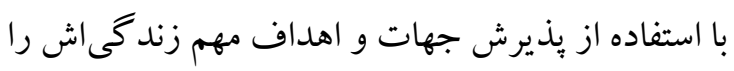

5- Huppert

6- Welsy

2- Bayoer, Molder

3- Keyse

4- Kadivar

5- Stiger, Rick. Beronk

5- Dieneer, Bisvas
خود را بيذيرند و خود را از كنترل قوانين كلامى كه سبب ايجاد مشكلاتشان گرديده است خلاص نمايد و و رون به آنها اجازه مىدهد كه از كشمكش و منازعه با آنها

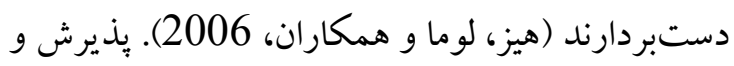
تعهد درمانى اساساً فرايند محور است و آشكارا بر ارتقا با بذيرش تجربيات روانشناختى و تعهد با افزايش فعاليت هاى معنا بخش انعطاف يذير، ناساز گارانه و بدون در نظر كرفتن محتواى تجربيات روانشناختى تأكيد مى كند. بذيرش و تعهد رويكردى است كه از

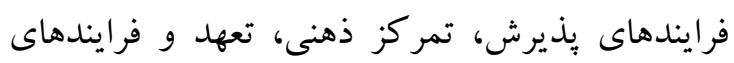
تغيير رفتار بهمنظور ايجاد انعطاف يذيرى شناخته استفاده مى كند (ايزدى، عابدى، 1394). اين يافتها همسو با بثزوهش هاى غيرمستقيمى است

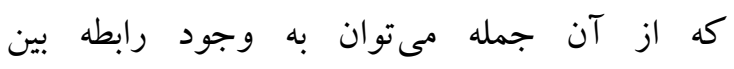
خود كارآمدى با بهزيستى روانشناختى، انسجام

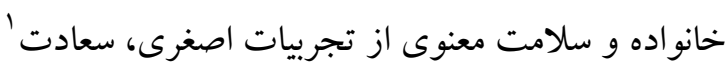

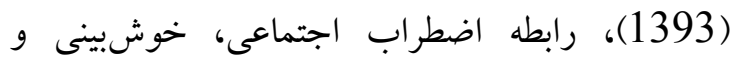
خود كارآمدى با بهزيستى روانشناختى بهادرى، خسروشاهى' (2012)، ارتباط حمايت اجتماعى و و رونى سبككهاى دلبستخى بر بهزيستى روانشناختى نادرى،

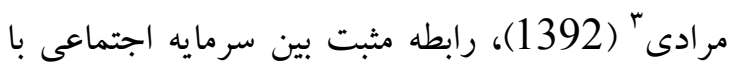

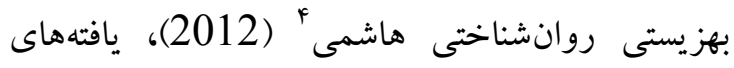
عسخرى مبنى بر رابطه بين حمايت اجتماعى و احساس روانس ذهنى بهزيستى (2013)، اثربخشى درمان مبتنى بر

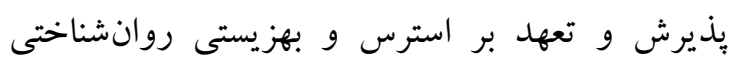

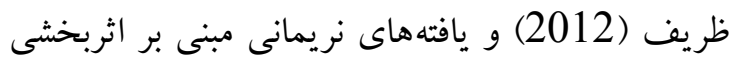

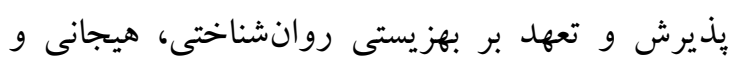

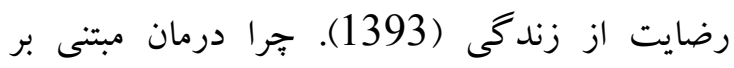
يذيرش و تعهد بر بهبود بهزيستى روانشناختى افراد

1- Asghari, Saadat

2- Bahadori, Khosroshahi

3- Naderi, Moradi

4- Hashemi 
بسيار مهم است، بذيرش خود نوعى بينش است كه

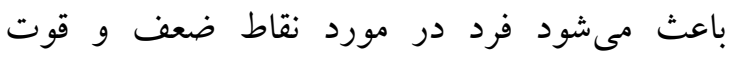
خويشتن به آكاهى واقعى برسد (ريف، سينگر،

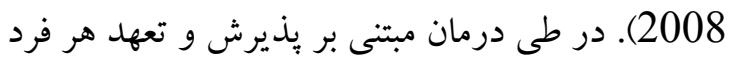
قادر مىشود جهت زندكى اش را انتخاب كند و هر كاه

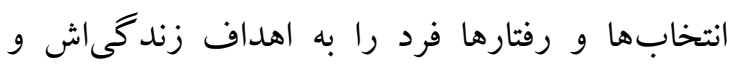
ارزشهايش نزديككتر كند يس زندگى او مؤثر است و باعث مىشود تسلط بر محيط در فرد افزايش يابد.

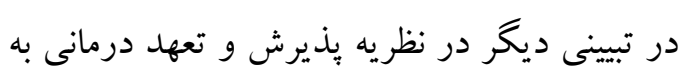
اين نكته در سلامت روان تأكيد دارد كه به جاى آنكه روى برطرف سازى و حذف عوامل آسيبزا تمركز

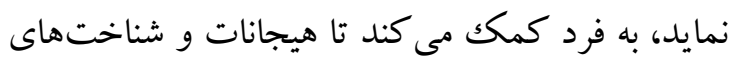
كنترلشده خود را بيذيرد و خود را از كنترل قوانين كلامى كه سبب ايجاد مشكلاتشان گرديده است خلاص نمايد و به آنها اجازه مى دهد كه از كشمكث إجش و منازعه با آنها دستبردارند (نريمانى، بخشايش،

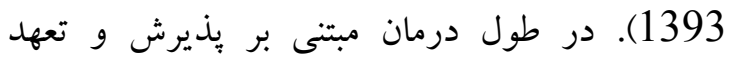

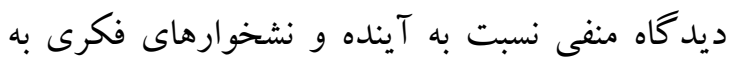
ديد گاههاى مثبت تبديل مى شود و اين موضوع باعث

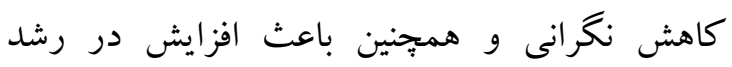
استقلال فردى در افراد مى شود. همجينين در اين درمان

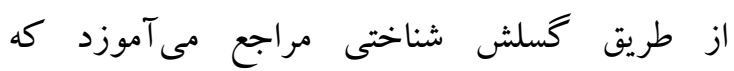
رويدادهاى درونى را همانطور كه واقعاً هستند را ببيند نه آنطور كه خود آن رويدادها مى گويند. اين در درون نهايت باعث مى شود فرآيند يذيرش بهتر رخ دهد.

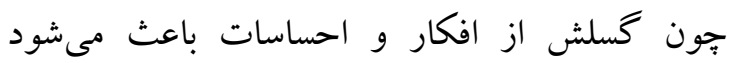
كاركرد اين رويدادهاى درونى بلهعنوان موانع روانشناختى كاهش يابد. در موقعيت هايى كه فرد افكار غيرمنطقى و ناراحت كنندهاى در مورد مشكل خود را تجربه مى كند، تنها حركت در اين موقعيتها اجتناب است. با تجربيات گسلش به مراجع كمك مى شود تا با فكر وسواسى به شيوه هاى متفاوت تعامل
انتخاب مى كند و اين عمل باعث افزايش هدف در

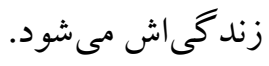
در تبينى ديخر بيان شده است كه در بهزيستى روانشناختى خودمختارى زمانى به وجود مى آيد كه ده بهـ فرد خود را دليل ييامدهاى فعاليت خود تشخيص دهد (بايوئر و مولدر'، 2006)، رشد شخصى يعنى اين افراد

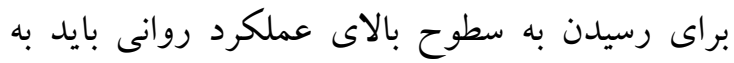

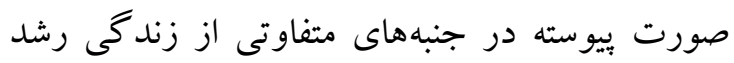
كند (ريف، 1989)، اين موضوع بيانگر آن است كه فرد به طور مداوم در كارها در گير شود و مشكلات را

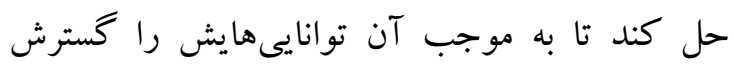
دهد. تسلط بر محيط به معناى توانايى فرد براى مديريت زندكى است، با اين توصيف فردى كه حس به تسلط بر محيط دارد مىتواند در جنبههاى مختلف

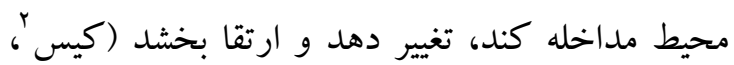
2002)، داشتن دركك روشنى از هدف در زندگى، مديط احساس جهت يابى و هدفمندى ويايه سلامت روانى به شمار مىرود، اين مقياس نيز به كمكك ويز گیىهايى

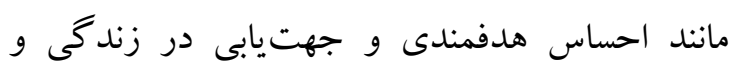

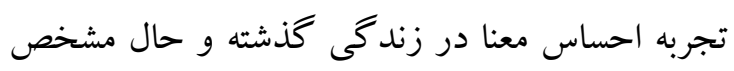
مىشود (ريف 1989، به نقل از كديورّ، 1387)، وجود هدف در زندگى به طور مثبت با رضايت از

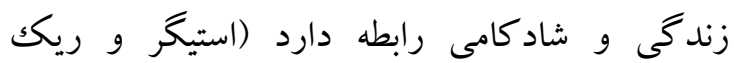

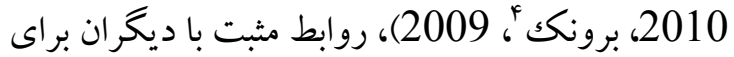

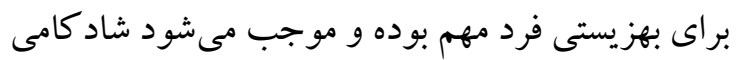

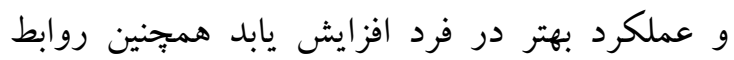

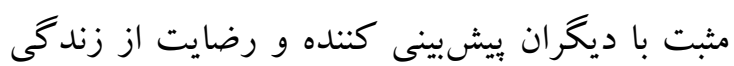

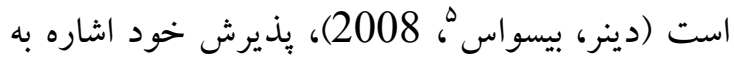

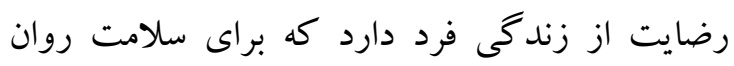


متفاوت با گروه همسالان و همجنسان خود مى باشد. اين افراد در زندگى در هويت جديدشان با به دستآوردن هويت ارضاءكننده براى خود و و احساس

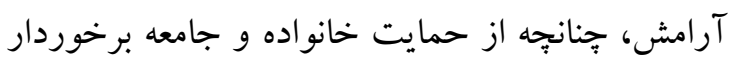
كردند با اميد به آينده بهتر به بهزيستى روانى و سلامت الته روان و زندگى سالم تر نزديكك مىشوند (يراقى،

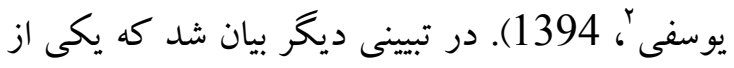
ضرورىترين و كاربردى ترين مباحثى كه در افرد

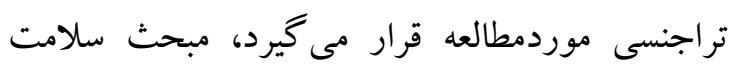
روان و كيفيت زندگى آنها است. اين موضوع با توجه به نياز مبتلايان به نارضايتى جنسيتى از اولويت بسيار

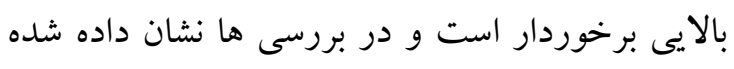
است كه در اين افراد شيوع انواع متفاوت آسيبهاى برح برداى روانى وجود دارد مانند هراس، جسمانى سازى و ولر حساسيت در روابط بين فردى است (عسگرى، 1386). آنجهه مسلم است اين است كه در جامعه ما با رول وجود نخرش هاى منفى در باب افراد مبتلا به اختلالات

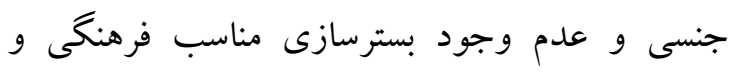
اجتماعى، اغلب اين افراد داراى وضعيت نابسامانى هستند و نبود مر اقبت هاى روانى - اجتماعى و همجِين إنين كاهش بهزيستى روانى افراد ترا جنسى و حتى لئى

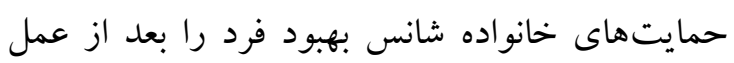
جراحى تغيير جنسيت بسيار كم مى كند و بر اين اساس عمل جراحى تغيير جنسيت به تنهايى كافى نبوده و لزوم افزايش سلامت روان و بهزيستى روانى اين افراد بهوسيلهى روان درمانيها و مشاورههاى مورد نياز همواره احساس مىشود (خوشدل، دكتر جفرودى و دكتر كنعانى، 1392).

2- Yaraghi, Yousefi
داشته باشد. در اين حالت ميزان اعتقاد به آن كاهش مى يابد، بنابراين فكر ممكن است به همان ميزان باشد،

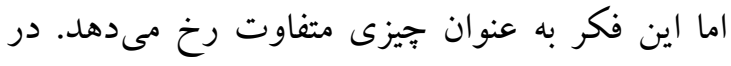

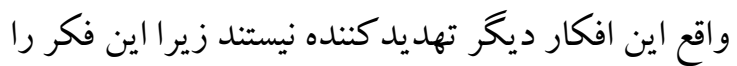
فقط فكر مىبينيد نه واقعيت. بنابراين بذيرش و تعهد از

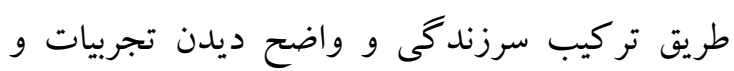

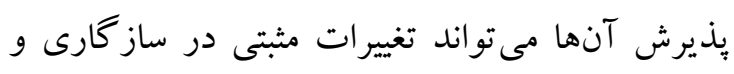
بهزيستى ايجاد نمايد. در تبينى ديخر اظهار داشته شد در ديد كاه درمان

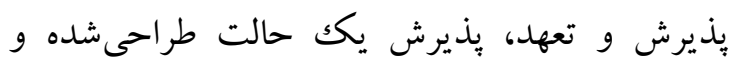

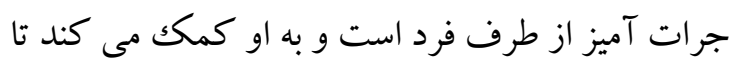
به طور كامل و بدن دفاع، جنبه هايى از تجربه هاى روانشناختى خود (بد، خوب و زشت) را همانكونه

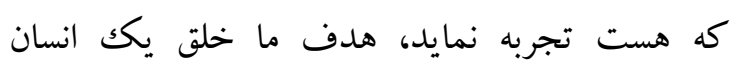
كارآمد است كه صميمانه با دنياى تجربى خود در هر هرد ارتباط باشد. بذيرش يعنى تجربهى حسها، عواطف و و

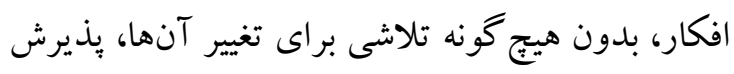

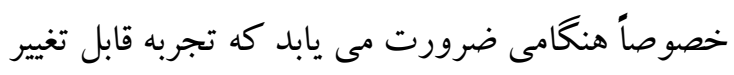
نيست و نبايد تغيير كند. اين حالت تناقض به فرد اجازه

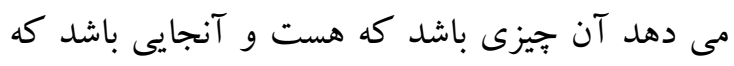
حضور دارد و تمايل به تغيير افكار و احساسات خود را بها كاهش دهد. وقتى لباس نگßرانى در مورد آينده،

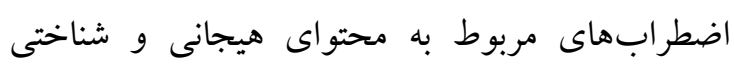
نامطلوب و وبريشانى حالات بدنى را از تن فرد

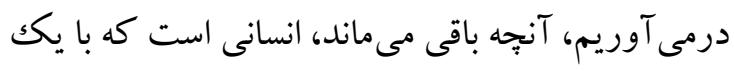
زندكى نا كار آمد (ايفرت و هفنر'، 2003).

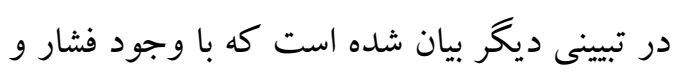

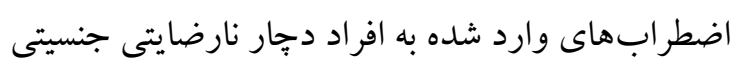
كه نتيجه دركك از تفاوتهاى خود، انتظارات و توقعات خانواده، تبعيض و برجسب هاى مختلف كه بر اثر

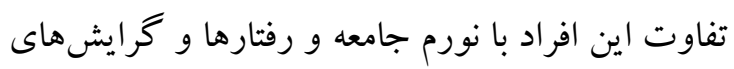


دوام درمان در فاصلههاى زمانى بيشتر، از جمله سه ماه و شش ماه پس از مداخله بوده كه به علت محدوديت مالى و زمانى و هممجنين عدم همكارى افراد در روند

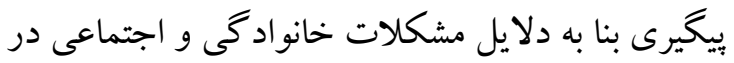

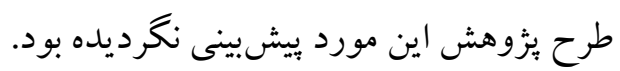

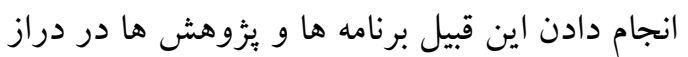
مدت به طور حتم مى تواند بر كاهش علائم منفى و افزايش بهزيستى روانشناختى افراد تراجنسى تاثير گذار باشد. با توجه به اين مسائل نيز بيشنهاد مىشود كه از طرف سازمان بهزيستى و كلينيكهاى روانشناسى توجه بيشترى به افراد تراجنسى شده تا اين افراد بتوانند در جامعه زندگى بهتر و سلامت روان بيشترى را داشته باشند.

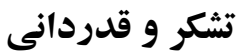

يثزوهش حاضر برگرفته از پايان نامه كارشناسى ارشد

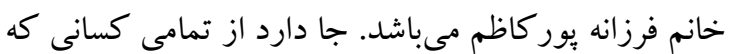
در تمامى مراحل اين يُزوهش از كادر دانشگاهى تأن كلينيكهاى نويد بخش و راه عشق و از جناب آقاى

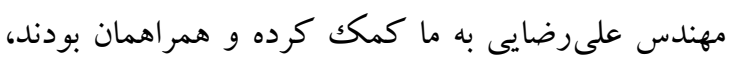
تشكر و سياسگزارى كنيم.

\section{References}

1. Alavi, K. Jalali Nadoushan, A.Eftekhar, M, (2014),Sexual orientation in people with sexual dysfunction, Journal of psychiatry and clinical psychology,20(1):43-49.]in persian[

2. Alavizadeh, F., Shakerian, A, (2016), Acceptance and Commitment therapy to reduce stress, anxiety and depresshion woman with a crossover experience, Journal of sciences research, 4(6):8-14. [in persian]

3. Asghari, F., Saadat, S., Atefi, S (2014), Relationship between academic selfefficancy, psychological Will-bing, family chosion and spiritual Will-bing in
نتايج اين بُزوهش نشان داد كه افزايش بهزيستى

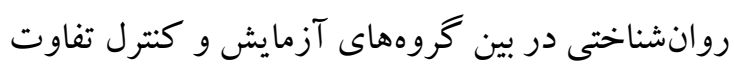
معنادارى وجود دارد؛ بهعبارتديخر درمان مبتنى بر يذيرش و تعهد با توجه به ميانگين بهزيستى روانشناختى افراد داراى اختلال نارضايتى جنسى (تراجنسى) گرووه آزمايش نسبت به ميانگين بهزيستى روانشناختى افراد داراى اختلال نارضايتى جنسى گروه كنترل موجب افزايش معنادار بهزيستى روانشناختى افر اد داراى اختلال نارضايتى جنسى كروه آزمايش شدهـ است؛ و همجنين با توجه به اهميت و ارزش سطح بهزيستى روانشناختى با اهداف بيشخير انه و ارتقا سطح سلامت روان، فقدان اين مهارت باعث كاهش بـ بـ ارزشمندى در فرد خواهد شد. درنتيجه بيشنهاد مىشود كه آموزش جنين مهارتهايى در افراد تراجنسى احساس كفايت، توانايى مؤثر بودن، غلبه كردن بر

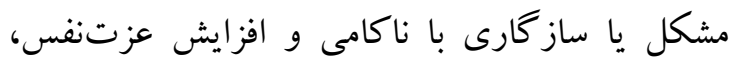

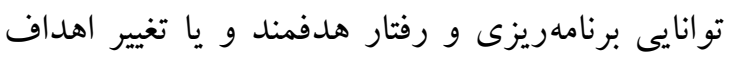
مواجه شده با ناكامى و متناسب با مشكل را به وجود ريد

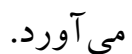

از جمله محدوديتهاى يُوهش نيز مىتوان به مقطعى بودن آن اشاره كرد. به عبارتى عدم اندازه گيرى

students at Kharazmi university, Journal of Medical Education,7(14):581-593. [in persian]

4. Asgari, M., Saberi, M., Rezaee, A., Dolatshahi,B, (2007), The prevalence of mental illness in patients with sexual dysfunction, Journal of forensic medicine, 3(47). [in persian]

5. Bahadori Khosroshahi, J., Babapour Kheirdin, J, (2013), The relashionship of social capital with psychological Wellbing in students of Tabriz University, Journal of social recognition, 2(6): 44-54. [in persian]

6. Bastami, M., Goudarzi, N, (2016), The Effeectiveness of Acceptance and 
Commitment therapy on reducing depression symptoms of military personnel with type 2 diabetes, Journal of scientific research, Naja Department of Health, 18(1). [in persian]

7. Bauer. J., \& Mulder. R. H. 2006. Upvard Feedback and ist Contribution to Employs Feeling of Self- Determination. Journal of Work plays Learning, 18(7/8). 509-515.

8. Bronk, K. C., Hll, p, 1., Lapsley, T, L., Talib, T.L., Finch, H. 2009. Purpose, hope, and Life Satisfaction in three age groups. Journal of positive psychology. 4 . 500- 510.

9. Chandra, A., Mosher, WD., Copen, C., Sionean, C, (2011), Sexual behavior, sexual attraction, and sexual identity in the United States: Data from the 2006-2008 national survey of family growth, Natl Health Stat Report, 36:1-36.

10. Drescher, J., Byne, W, (2009), Homosexuality, gay and lesbian identity and homosexual behavior. In: Sadock JS,Baltimore MD: Lippincott Williams \& Wilkins.

11. Diener, E. \& Biswas-Diener, R. 2008. Happiness: Unlocking the Mysteries of Psychological Wealth. BlackwellWiley.

12. Eifert, GH. Heffner, M. 2003. The effects of acceptance versus control contexts on avoidance of panic-related symptoms. Journal of Behavor Therapy and Experimental Psychiatry, 34,293-312.

13. Ghaedi,GH., Yaghubi,H, (2008), The Relationship between perceived social support Dimensions and welfare Dimensions in male and female students, Journal of Armaghan Danesh, 13(2):50. [in persian]

14. Ghomian, S., Shaeeri, M,(2014), Designing a treatment protocol based on admission and commitment for children with chronic pain and impact on the Willbing and psychological flexibility of children, Journal of Sciences research, 12(4). [in persian]

15. Hayes, S.C. 2004. Acceptance and Commitment Therapy, relational frame theory and the third wave of behavioral and cognitive therapies. Behavior Therapy. 35 (4): 639-650.

16. Hayes, S.C. Luoma, J.B. Bond, FW, Lilli, S.J. Acceptance and Commitment therapy: model, Behavior

17.Huppert F, 2008.Psychological Wellbeing: Evidence regarding its causes and consequences - State-of-Science Review: SR-X2, Government Office for Science Foresight Project. Mental Capital and Wellbeing: Making the most of ourselves in the 21 st Century.

18. Izadi, R., Abedi, M, (2015), Acceptance and Commitment therapy, 160 p. [in persian]

19. Keyes C L M, Shmotkin D. Ryff C D. 2002. Optimizing Well-Bing: The empirical enchanter of two traditions. Journal of Personality and Social Psychology, (82): 1007-1022.

20. Khoshdel, M., Jefroudi, M., Kanani, M,(2013), A survey on the changein satisfaction of life in persons changing the gender in Rasht, Masters, Islamic Azad University of Rasht. [in persian]

21. Matinfar, M., Abedi, M, (2016), Acceptance and Commitment therapy to life expectancy and Exposure to woman in prison, Masters, Islamic Azad University of Najaf Abad. [in persian]

22. Moghtadaie, F., Reisee, Z,(2015), Acceptance and Commitment therapy of psychological Well-bing of veterans wives, Journal of vetern medicine, 7(4). [in persian]

23. Naderi, R., Moradi, A., Mobasheri, M, (2012), Investigation the relashionship between social support and attachment Styles pregnant woman in Boroujen, Journal of Nursing and midwifery Clinical, 2(4). [in persian]

24. Narimani, M., Bkhshayesh, R, (2014), Acceptance and Commitment therapy to psychological Well-bing Emotion and marital satisfaction of married couples are subject to divorce, journal of consulting research, 13(52). [in persian] 
25. Rahimian, B, (2007), What is Psychologhical Well-bing and where dose it come from? Journal of the health and community spirit, 20: $22-25$. [in persian]

26. Ryff, C.D. \& Keyes, C.L. 1995. The Structure of Psychological Well-being Revisited, Journal of Personality and Social Psychology, 69: 719-727.

27. Ryff C D, 1989.Happinessis every Thing.or is it? Expiorations on the meaning of Psychological Well-Bing. Journal of personality and social psychology.; 5(6): 1069-1087.

28. Ryff, C.D., Singer, B.H., \& Love, G.D., 1998. Positive health: Connecting.

29. Ryff C D, Singer B H, 2008. Know They Self and become what you are; A Eudaimonic Approach to Psychological Well-Bing. Journal of Happiness Studies, 9,13-39.

30. Saadatmand, Kh., Basaknejad, S, (2016), Acceptance and Commitment therapy of intimacy, for giveness and psychological Well-bing of couples, Masters, Shahid Chamran University. [in persian]

31. Sabour, S., Kakabaraie, K, (2016), The Efficancy of admission Group Acceptance and Commitment therapy to Depression and stress and pain in woman with chronic pain, Journal of sciencess, 2(4): 1-10. [in persian]

32. Sadock, B.J. Sadock, V. A. \& Ruiz, P. 2015. Kaplan and Sadock's synopsis of psychiatry: Behavioral sciences/ clinical psychiatry (11th ed). Philadelphia, PA. [in persian]

33. Sadock VA, Ruiz P. editors. Kaplan \& Sadock's comprehensive textbook of psychiatry. 9th ed.

34. Sedighi, F., Reesi, Z, (2015), Acceptance and Commitment Therapy of Mental Health and Psychological Weelbing of wives of dependent patients, Masters, Islamic Azad University of Najaf Abad. [in persian]

35. Varaie, A., Daneshparvar, H., Elkhaninejad, T,(2013), The stady of social factors affecting gender identity disorder, Journal of professional, 6(2): 936. [in persian]

36. Wells I E. 2010. Psychological Well-Bing, Psychology of Emotion, Motivations And Actions, Nova Science Publi Shers, Inc. New York.

37. Yaraghi, M., Yousefi, Z, (2015), Study of the decomposition of people with gender identity disorder befor and after changing the identity of Esfahan, Masters, Islamic Azad University Khorasgan. [in persian]

38. Zarif golbaryazdi, H., Aghamohamadi, H, (2012), The effectiveness of welfare treatment on Stress and Psychological Will-bing of in fertile woman Mashhad, faculty of Education sciences, Ferdos University, 15(2): 49-56. [in persian] 